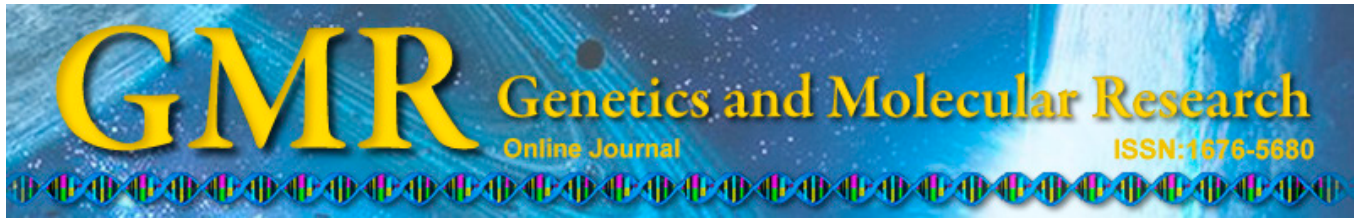

\title{
Selection of maize hybrids for tolerance to aluminum in minimal solution
}

\author{
C.J. Coelho ${ }^{1}$, D. Molin ${ }^{2}$, H.A. Wood Joris ${ }^{1}$, E.F. Caires ${ }^{1}$, \\ J.R. Gardingo ${ }^{1}$ and R.R. Matiello ${ }^{1,2}$ \\ ${ }^{1}$ Programa de Pós-Graduação em Agronomia, \\ Universidade Estadual de Ponta Grossa, Ponta Grossa, PR, Brasil \\ ${ }^{2}$ Programa de Pós-Graduação em Biologia Evolutiva, \\ Universidade Estadual de Ponta Grossa, Ponta Grossa, PR, Brasil \\ Corresponding author: R.R. Matiello \\ E-mail: rrmatiel@uepg.br
}

Genet. Mol. Res. 14 (1): 134-144 (2015)

Received March 21, 2014

Accepted July 26, 2014

Published January 15, 2015

DOI http://dx.doi.org/10.4238/2015.January.15.16

\begin{abstract}
The aim of this study was to determine the $\mathrm{Al}$ concentration and the period of exposure of the roots of maize hybrids in minimal solution for efficient selection of genotypes that are Altolerant. Two experiments were performed ( 48 and $96 \mathrm{~h}$ of exposure) with increasing doses of $\mathrm{Al}$ in minimal solution; the block design was completely randomized in a split-plot design with 3 replications. By assessing differences in root growth $(\mathrm{cm})$ and the percentage of inhibition of the growth of the main root (\%), a marked decrease was observed in maize root growth with increasing $\mathrm{Al}$ concentration in the solution. Exposure of the roots to $2 \mathrm{mg} / \mathrm{L} \mathrm{Al}$ for $48 \mathrm{~h}$ in minimal solution was the most efficient for selecting sources of tolerance, particularly for the hybrids H 44 and $\mathrm{H} 38$.
\end{abstract}

Key words: Difference in root growth; Inhibition; Root length; Sources of tolerance 


\section{INTRODUCTION}

In many areas of the world, soil acidity limits agricultural yield. In Brazil, it is estimated that more than 500 million hectares of land are composed of acidic soils, comprising approximately two-thirds of the country (Vitorello et al., 2005). Low levels of basic cations, particularly calcium $(\mathrm{Ca})$, as well as the toxicity of aluminum $(\mathrm{Al})$ have the most limiting effect on crop productivity in acid soils in tropical and subtropical regions (Coleman and Thomas, 1967). In general, the adverse effects of $\mathrm{Al}$ are reflected in the roots, which grow at a slower rate. Because of the interference of $\mathrm{Al}$ in the cell division process, the roots paralyze plant growth and exhibit profound morphological changes. They subsequently thicken and show abnormal branching (Doncheva et al., 2005). Maize is one of the crops most affected by Al toxicity, resulting in yield reductions in excess of $80 \%$ (Conceição et al., 2009).

The problems caused by soil acidity, and thus Al toxicity, are commonly corrected by lime application. In areas that are prepared conventionally, topsoil acidity is neutralized by mechanically incorporating lime, inducing reaction between the lime and the soil. In no-till systems, lime cannot be mixed with the soil and is instead applied to the surface (Caires et al., 2008). As the reaction of lime is typically limited to the site of its application in the soil, acidity in the subsurface layers (in the case of toxic levels of $\mathrm{Al}$ ) can compromise the root growth, affecting plant nutrition and leaving crops susceptible to water stress (Caires et al., 2005). Thus, choosing plants with genotypes that are adapted to acidic conditions along with more efficient nutrient use is important for increasing the sustainability of conservation agriculture (Parentoni et al., 2001).

Selecting for aluminum tolerance in the field is very complex, laborious, and subject to various errors. The natural variability of soils and the difficulty of assessing the root damage result in failures in genotype selection (Mazzocato et al., 2002). Assessing damage to the root system of seedlings in nutrient solution containing $\mathrm{Al}$ at toxic concentrations has been effectively adopted for selecting highly tolerant genotypes (Jorge and Arruda, 1997; Mazzocato et al., 2002; Paterniani and Furlani, 2002; Alves et al., 2004; Piñeros et al., 2005).

Clark's complete nutrient solution (Clark, 1975) has become the basis for most studies examining Al tolerance (Magnavaca, 1982; Furlani and Furlani, 1988; Maron et al., 2008). However, there are limitations to using complete nutrient solution, as Al can interact with phosphate and sulfate to form poorly soluble compounds and could decrease $\mathrm{Al}$ activity in the solution. Some previous studies have proposed the use of minimal solution containing $\mathrm{Ca}$ and $\mathrm{Al}$ for the characterization of Al-tolerant genotypes (Mazzocato et al., 2002; Conceição et al., 2009). However, the $\mathrm{Al}$ concentrations and time of exposure of the roots in minimal solution for characterization of maize genotypes tolerant to Al have not been thoroughly described. Thus, in this study, we determined the concentration of $\mathrm{Al}$ and time of exposure of maize roots in minimal solution for selecting Al-tolerant maize hybrids.

\section{MATERIAL AND METHODS}

Two experiments using 8 commercial hybrids from different companies [H 13 and H 14 (Pioneer Hi-Bred International, Johnston, IA, USA); H 22 and H 30 (Syngenta, Basel, Switzerland); and H 38, H 43, H 44, and H 5 (Dow AgroSciences, Indianapolis, IN, USA)] were performed at the Laboratory of Plant Breeding of the Universidade Estadual de Ponta Grossa in Paraná State, Brazil. The seedling roots from different hybrids were exposed to Al for $48 \mathrm{~h}$ in the first experiment and $96 \mathrm{~h}$ in the second. 
Hybrid seeds were placed on germination paper rolls $\left(\right.$ Germitest $\left.^{\circledR}\right)$ in a germination chamber for 4 days at a temperature of $25^{\circ} \mathrm{C}$ and a photoperiod of $12 \mathrm{~h}$. After pre-germination, the seedlings (main root was 3.5-4.5 cm) were placed in minimal solution containing $40 \mathrm{mg} / \mathrm{L}$ $\mathrm{Ca}\left(\mathrm{CaCl}_{2} \cdot 2 \mathrm{H}_{2} \mathrm{O}\right)$ and $\mathrm{Al}$ concentrations of $0,2,4$, and $6 \mathrm{mg} / \mathrm{L}$ in the form of aluminum chloride $\left(\mathrm{AlCl}_{3} \cdot 6 \mathrm{H}_{2} \mathrm{O}\right)$. Experiments were conducted in a completely randomized block, with a split-plot design with 3 replications. The $\mathrm{Al}$ concentrations were used in the plots and the 8 corn hybrids were used in the subplots, using 12 seedlings per replication of each hybrid at the respective concentrations of $\mathrm{Al}$.

The initial length of the main root (IL-cm) was measured before transferring the seedlings to 96 -well polystyrene trays $(12 \times 8)$. The trays were then deposited in transparent plastic pots with $8 \mathrm{~L}$ minimal solution containing the varying $\mathrm{Al}$ concentrations. The main root of the seedlings remained in minimal solution $(\mathrm{Al}+\mathrm{Ca}$ ) for $48 \mathrm{~h}$ (first experiment) and $96 \mathrm{~h}$ (second experiment) with uniform and constant aeration. The $\mathrm{pH}$ of all solutions was adjusted from 4.2-4.6 using a solution of $1 \mathrm{M} \mathrm{NaOH}$. After the exposure periods (48 and $96 \mathrm{~h}$ ), the final length of the main root (FL-cm) of all seedlings was measured again. The difference between IL and FL (FL-IL) was identified as DIF ( $\mathrm{cm}$ ) based on the method proposed by Mazzocato et al. (2002).

DIF variable data for both experiments were subjected to analysis of variance. In the presence of a significant effect of the hybrid x Al concentration interaction, we analyzed the decomposition of $\mathrm{Al}$ concentrations for each hybrid studied using regression analysis. The regression equations were adjusted using the square root model. The decomposition of the hybrids within the $\mathrm{Al}$ concentration was performed using the Student $t$-test at $5 \%$ for the 2 experiments. In addition, the inhibition of growth of the main root (IGMR, in \%) was calculated for the 8 hybrids at concentrations of 2, 4, and $6 \mathrm{mg} / \mathrm{L} \mathrm{Al}$, as well as during the 2 exposure times (48 and 96 h) using (Equation 1) proposed by Cambraia and Cambraia (1995). Analyses of variance and tests of means were performed using the statistical program SISVAR, version 5.3 (Ferreira, 2011) and regression analyses was performed using the SAEG program, version 9.1 (Ribeiro and Melo, 2008).

$$
\operatorname{IGMR}(\%)=\left[\frac{100-\left(D I F_{+A l} \times 100\right)}{D I F_{-A l}}\right]
$$

\section{RESULTS AND DISCUSSION}

Analysis of variance for both experiments revealed a significant effect of the interaction hybrid $\mathrm{x}$ concentration of Al for the DIF variable (Table 1). The effect of Al concentrations on each hybrid maize after $48 \mathrm{~h}$ revealed a large reduction in the DIF variable of all hybrids with increasing $\mathrm{Al}$ concentrations in solution (Figures 1 and 2). The reduction in the length of the main primary root of hybrids was most pronounced with $2 \mathrm{mg} / \mathrm{L} \mathrm{Al}$ in the solution; the effect was attenuated from $2-4 \mathrm{mg} / \mathrm{L}$, and relatively stable from $4 \mathrm{mg} / \mathrm{L}$. After exposing the roots to $\mathrm{Al}$ for $96 \mathrm{~h}$ (Figures 3 and 4), the responses of hybrids were similar to those observed at $48 \mathrm{~h}$. Over the 2 periods of exposure to $\mathrm{Al}$ ( 48 and $96 \mathrm{~h}$ ), reduced root growth of the maize hybrids was evident at $2 \mathrm{mg} / \mathrm{L} \mathrm{Al}$ in solution. 
Table 1. Summary of analysis of variance for the difference in root growth (DIF) for different Al concentrations in minimal solution and 2 periods of exposure for 8 maize hybrids.

\begin{tabular}{|c|c|c|c|}
\hline \multirow[t]{3}{*}{ Source of variation } & \multicolumn{3}{|c|}{ Mean squares (MS) } \\
\hline & \multirow[t]{2}{*}{ d.f. } & \multicolumn{2}{|c|}{ DIF } \\
\hline & & $48 \mathrm{~h}$ & $96 \mathrm{~h}$ \\
\hline Blocks & 2 & 1.03 & 1.60 \\
\hline Al concentrations $(\mathrm{C})$ & 3 & $248.51 * *$ & $1179.93 * *$ \\
\hline Error (a) & 6 & 0.27 & 1.80 \\
\hline Hybrids (H) & 7 & $3.18 * *$ & $7.61 *$ \\
\hline $\mathrm{C} \times \mathrm{H}$ & 21 & $0.96 * *$ & $8.39 * *$ \\
\hline Error (b) & 56 & 0.16 & 3.40 \\
\hline \multicolumn{4}{|l|}{ Decomposition $(\mathrm{C} \times \mathrm{H})$} \\
\hline 0 & 7 & $3.39 * *$ & $30.55 * *$ \\
\hline 2 & 7 & $1.21 * *$ & 0.81 \\
\hline 4 & 7 & $0.75 * *$ & 1.04 \\
\hline 6 & 7 & $0.70 * *$ & 0.39 \\
\hline $\mathrm{CV}_{\text {plot }}(\%)$ & & 12.6 & 21.2 \\
\hline $\mathrm{CV}_{\text {subplot }}^{\text {plot }}(\%)$ & & 9.6 & 29.2 \\
\hline Means & & 4.11 & 6.32 \\
\hline
\end{tabular}

$* \mathrm{P}<0.05$ and $* * \mathrm{P}<0.01$.
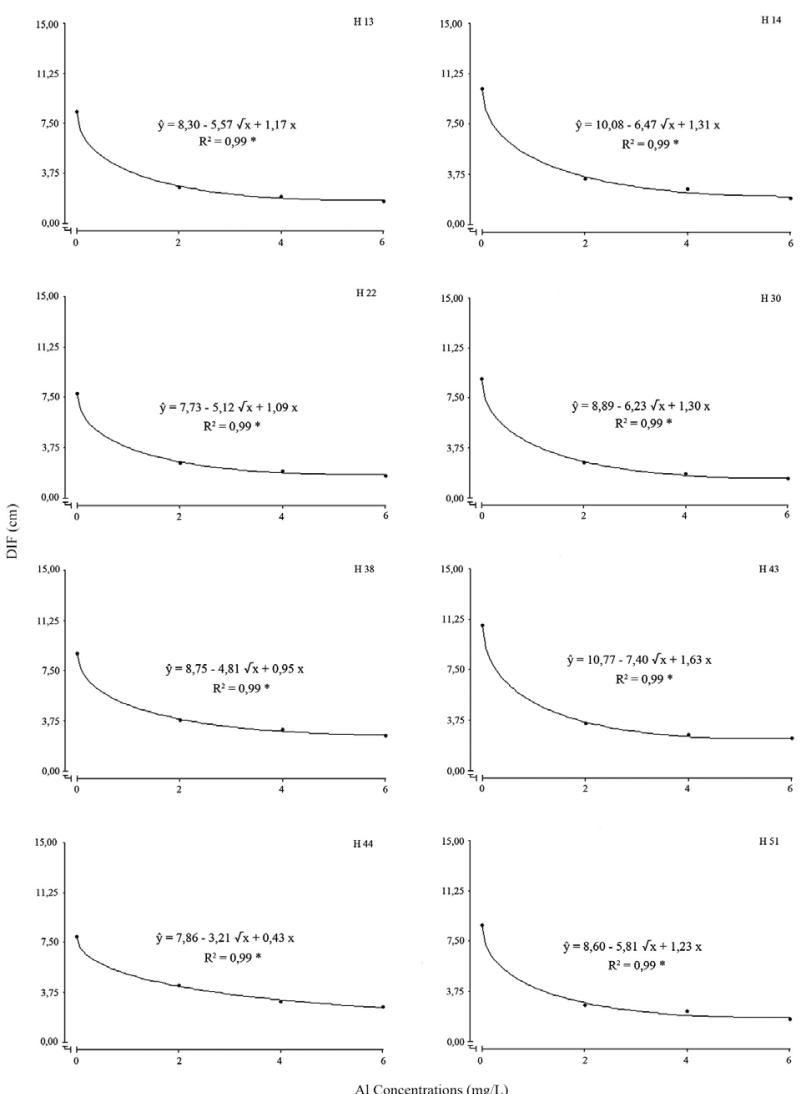

Figure 1. Decomposition effect of $\mathrm{Al}$ concentrations $(0,2,4$, and $6 \mathrm{mg} / \mathrm{L})$ for each hybrid using the square root regression model for the DIF variable (48 h exposure). $* \mathrm{P}<0.05$. 


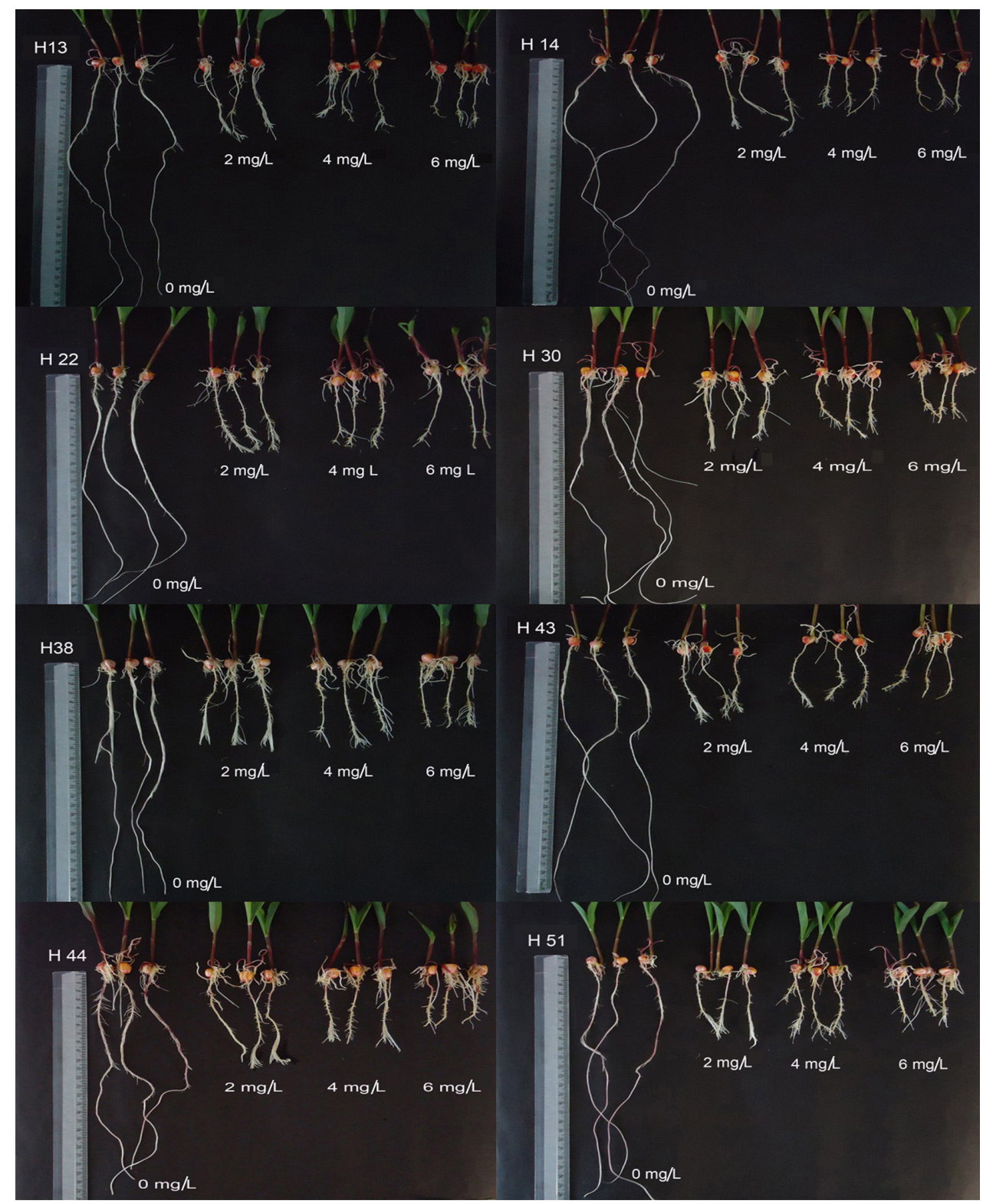

Figure 2. Effect of Al concentrations (0, 2, 4, and $6 \mathrm{mg} / \mathrm{L})$ on the hybrids $(\mathrm{H} 13, \mathrm{H} 14, \mathrm{H} 22, \mathrm{H} \mathrm{30}, \mathrm{H} 38, \mathrm{H} 43, \mathrm{H}$ 44, and $\mathrm{H} \mathrm{51)}$ after $48 \mathrm{~h}$ exposure.

The DIF averages for the 8 hybrids exposed to different Al concentrations for $48 \mathrm{~h}$ are shown in Figure 5A. In the absence of Al, there was wide variation in root growth between the hybrids, with the largest DIF found for hybrid H 43 and the lowest for hybrids H 44, H 22, and $\mathrm{H}$ 13. This may have resulted from genetic differences between the hybrids in the early growth phase of the seedlings (Figure 5A). Changes in the ranking of the hybrids in the absence of 
Al were observed following exposure to increasing $\mathrm{Al}$ concentrations. At $2 \mathrm{mg} / \mathrm{L} \mathrm{Al}$, greater root growth of hybrids $\mathrm{H} 44(4.3 \mathrm{~cm})$ and $38 \mathrm{H}(3.8)$ was observed, whereas the $\mathrm{H} 13, \mathrm{H} \mathrm{51}$, $\mathrm{H} 30$, and $\mathrm{H} 22$ hybrids showed the least root growth, ranging from $2.6-2.7 \mathrm{~cm}$, confirming the greater sensitivity of these hybrids to $\mathrm{Al}$ (Figure 5A). Exposure for $48 \mathrm{~h}$ at a concentration of $4 \mathrm{mg} / \mathrm{L} \mathrm{Al}$ also showed greatest root growth for the hybrids $\mathrm{H} 44(3.0 \mathrm{~cm})$ and $\mathrm{H} 38(3.1$ $\mathrm{cm}$ ); however, there was no significant difference from the $\mathrm{H} 43$ and $\mathrm{H} 14$ hybrids. In contrast, hybrids H 22 and H 30 showed DIFs of only 1.9 and $1.8 \mathrm{~cm}$, respectively. Exposure for $48 \mathrm{~h}$ at $6 \mathrm{mg} / \mathrm{L} \mathrm{Al}$ maintained the hybrids $\mathrm{H} 44, \mathrm{H} \mathrm{38}$, and $\mathrm{H} 43$ with greater root growth, while the hybrids H 22, H 51, H 13, and H 30 showed the least root growth (Figure 5A). These results indicate the greater tolerance of the hybrids $\mathrm{H} 44$ and $\mathrm{H} 38$ to $\mathrm{Al}$, as well as the higher sensitivity of hybrids H 13, H 22, H 30, and H 51 to Al. Even following exposure to increasing concentrations of Al, the hybrids $\mathrm{H} 44$ and $\mathrm{H} 38$ stood out because their root growth was statistically higher than the other hybrids, confirming that they are sources of Al-tolerance in maize. Other authors (Mazzocato et al., 2002; Conceição et al., 2009) also found significant differences in $\mathrm{DIF}$ values for maize genotypes after $48 \mathrm{~h}$ of exposure to $\mathrm{Al}$ in minimal solution $(\mathrm{Ca}+\mathrm{Al})$.
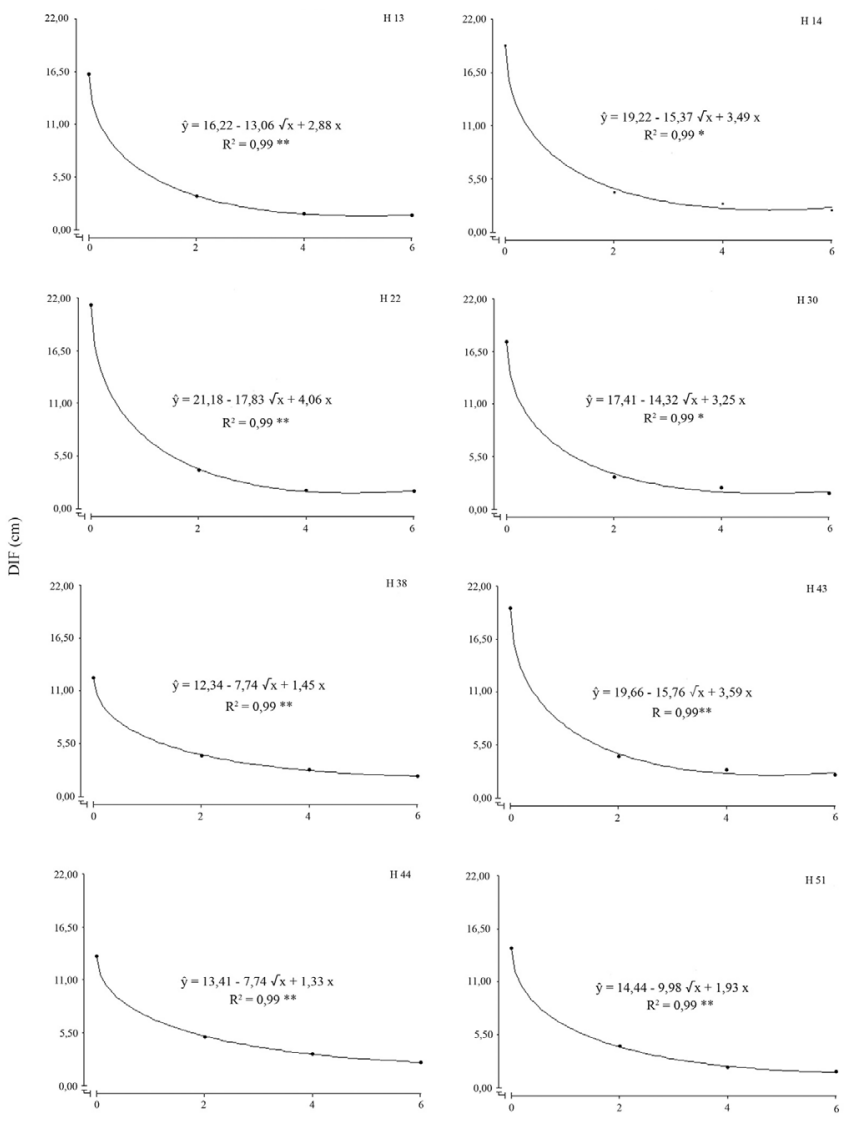

Figure 3. Decomposition effect of $\mathrm{Al}$ concentrations $(0,2,4$, and $6 \mathrm{mg} / \mathrm{L})$ for each hybrid using the square root regression model for the DIF variable ( $96 \mathrm{~h}$ exposure). $* \mathrm{P}<0.05$ and $* * \mathrm{P}<0.01$. 


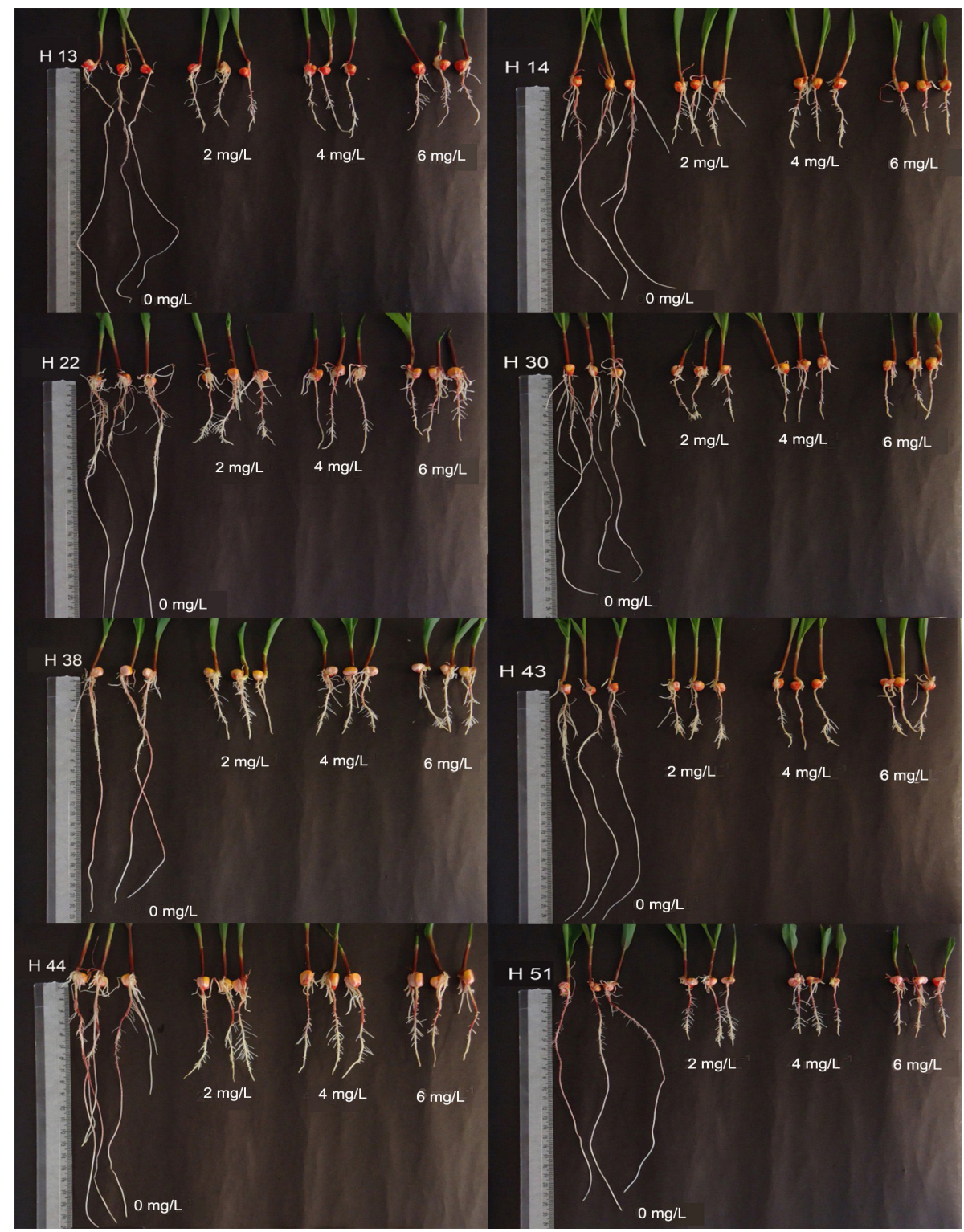

Figure 4. Effect of Al concentrations (0, 2, 4, and 6 mg/L) on the hybrids (H 13, H 14, H 22, H 30, H 38, H 43, H 44, and H 51) after $96 \mathrm{~h}$ exposure.

Other studies carried out in complete nutrient solution showed significant differences between maize genotypes, even after long periods of Al exposure (Cambraia and Cambraia, 1995; Jorge and Arruda, 1997; Piñeros et al., 2005). However, in all studies performed using minimal solution $(\mathrm{Ca}+\mathrm{Al})$, the maize roots were exposed for a maximum of $48 \mathrm{~h}$. In the present study, we increased the exposure period of the hybrids to Al to $96 \mathrm{~h}$ to confirm the genetic potential of Al-tolerance in hybrids that had previously been classified as tolerant (48 h). 


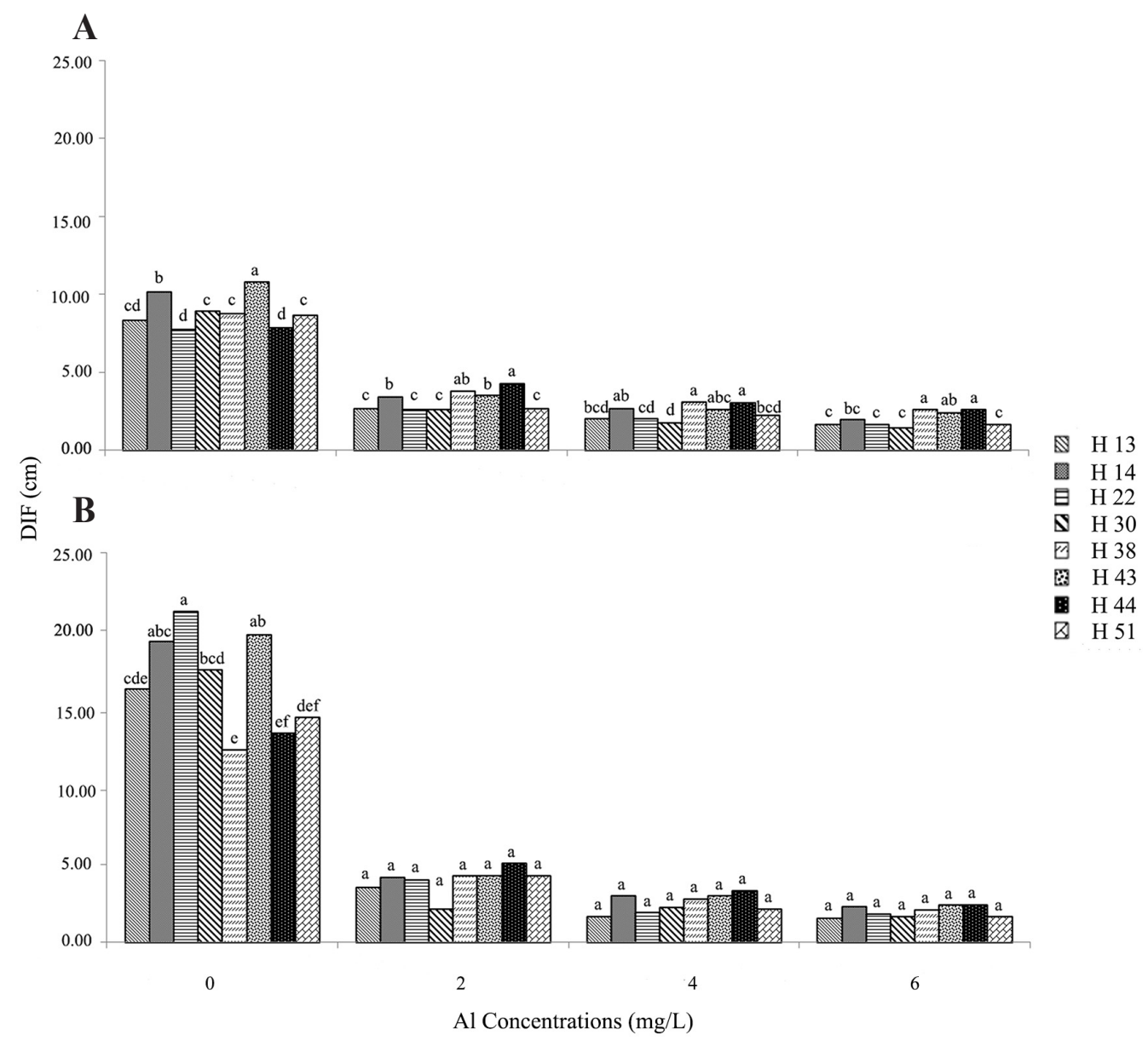

Figure 5. Effect of the decomposition of the hybrids (H 13, H 14, H 22, H 30, H 38, H 43, H 44, and H 51) in the respective concentrations of $\mathrm{Al}(0,2,4$, and $6 \mathrm{mg} / \mathrm{L})$. A. DIF ( $48 \mathrm{~h}$ exposure) and B. DIF ( $96 \mathrm{~h}$ exposure). Means followed by the same letter in each Al concentration did not differ statistically from each other according to the Student $t$-test at $5 \%$ probability.

The partition of the interaction of the hybrids within each Al concentration after $96 \mathrm{~h}$ of exposure showed no significant differences in DIF values between the hybrids at 2, 4, and $6 \mathrm{mg} / \mathrm{L} \mathrm{Al}$ (Figure 5B). Significant changes $(\mathrm{P}<0.01)$ only occurred in the absence of Al, potentially because of genotypic differences among the hybrids in the early growth phase of the seedlings. Under this condition, hybrid H 22 showed a DIF of $21.2 \mathrm{~cm}$, but this value did not differ significantly from those of hybrids H 43, H 14, and H 30 (Figure 5B). In this experiment, no significant differences in DIF values at different $\mathrm{Al}$ concentrations were observed among the hybrids. The $96 \mathrm{~h}$ exposure to $\mathrm{Al}$ was very long and may have caused large effects on the rate of cell division and elongation of the principal root. This fact prevented the detection of possible differences in tolerance/sensitivity among the studied hybrids. Thus, exposure of maize seedlings to $\mathrm{Al}$ for longer periods should only be performed when using complete 
nutrient solution because of the reduced nutrient reserves contained in the seeds. Several studies have found significant differences among genotypes for Al tolerance when exposed to complete nutrient solution for a period of more than $96 \mathrm{~h}$ (Jorge and Arruda, 1997; Paterniani and Furlani, 2002; Alves et al., 2004; Piñeros et al., 2005).

The reduction in root growth of the maize hybrids increased with increased Al concentrations in the minimal solution, and this effect was observed for both 48 and $96 \mathrm{~h}$ of exposure. Cambraia et al. (1991) observed similar results when evaluating 2 sorghum cultivars in complete nutrient solution with $2,4,6,8$, and $10 \mathrm{mg} / \mathrm{LAl}$. These authors found significant differences among the cultivars up to $4 \mathrm{mg} / \mathrm{L}$ above which a level of stability was reached; the largest differences in root growth were detected with $2 \mathrm{mg} / \mathrm{L}$. Cambraia and Cambraia (1995) studied $\mathrm{Al}$ concentrations $(0,5,10$, and $20 \mathrm{mg} / \mathrm{L})$ in complete nutrient solution for the hybrids BR 126 and BR 136 and suggested $5 \mathrm{mg} / \mathrm{L}$ for selecting Al-tolerant hybrids because higher concentrations generally eliminated differences between hybrids.

The IGMR values for the main root of the hybrids showed significant reductions in main root growth, both by increasing $\mathrm{Al}$ concentrations as well as increasing the root exposure period (Table 2). The mean IGMR observed for $48 \mathrm{~h}$ exposure to $\mathrm{Al}$ was $71.2 \%$, with a range of $63.3(2 \mathrm{mg} / \mathrm{L})$ to $77.4 \%(6 \mathrm{mg} / \mathrm{L})$. The greatest effect in average IGMR was demonstrated at $96 \mathrm{~h}$ exposure $(82.4 \%)$, ranging from $74.0(2 \mathrm{mg} / \mathrm{L})$ to $87.8 \%(6 \mathrm{mg} / \mathrm{L})($ Table 2$)$.

Table 2. Effect of Al concentrations (2, 4, and $6 \mathrm{mg} / \mathrm{L}$ ) and exposure period (48 and $96 \mathrm{~h}$ ) on inhibition of growth of the main root (IGMR) in 8 maize hybrids.

\begin{tabular}{|c|c|c|c|c|}
\hline \multirow[t]{2}{*}{ Hybrids } & \multicolumn{4}{|c|}{ IGMR $(\%)-48$ h } \\
\hline & $2 \mathrm{mg} / \mathrm{L}$ & $4 \mathrm{mg} / \mathrm{L}$ & $6 \mathrm{mg} / \mathrm{L}$ & Means \\
\hline H 30 & $70.7^{\mathrm{a}}$ & $80.2^{\mathrm{a}}$ & $84.2^{\mathrm{a}}$ & 78.4 \\
\hline H 51 & $68.9^{\mathrm{a}}$ & $74.0^{\mathrm{b}}$ & $80.9^{\mathrm{ab}}$ & 74.6 \\
\hline H 13 & $67.8^{\mathrm{a}}$ & $75.8^{\mathrm{ab}}$ & $80.5^{\mathrm{ab}}$ & 74.7 \\
\hline H 43 & $67.6^{\mathrm{a}}$ & $76.0^{\mathrm{ab}}$ & $78.0^{\mathrm{b}}$ & 73.9 \\
\hline H 14 & $66.8^{\mathrm{a}}$ & $74.0^{\mathrm{b}}$ & $80.8^{\mathrm{ab}}$ & 73.9 \\
\hline Н 22 & $66.4^{\mathrm{a}}$ & $74.3^{\mathrm{ab}}$ & $78.6^{\mathrm{ab}}$ & 73.1 \\
\hline Н 38 & $57.0^{\mathrm{b}}$ & $64.8^{c}$ & $70.1^{\mathrm{c}}$ & 63.8 \\
\hline H 44 & $45.6^{\mathrm{c}}$ & $61.0^{\mathrm{c}}$ & $66.2^{\mathrm{c}}$ & 57.6 \\
\hline \multirow[t]{2}{*}{ Means } & 63.3 & 72.5 & 77.4 & 71.4 \\
\hline & \multicolumn{4}{|c|}{ IGMR (\%) - 96 h } \\
\hline Н 30 & $80.6^{\mathrm{a}}$ & $87.2^{\mathrm{a}}$ & $90.6^{\mathrm{a}}$ & 86.1 \\
\hline Н 22 & $79.1^{\mathrm{a}}$ & $90.0^{\mathrm{a}}$ & $90.7^{\mathrm{a}}$ & 86.6 \\
\hline H 14 & $78.5^{\mathrm{a}}$ & $84.6^{\mathrm{a}}$ & $88.3^{\mathrm{ab}}$ & 83.8 \\
\hline H 13 & $78.4^{\mathrm{a}}$ & $89.9^{\mathrm{a}}$ & $90.7^{\mathrm{a}}$ & 86.3 \\
\hline H 43 & $78.4^{\mathrm{a}}$ & $85.0^{\mathrm{a}}$ & $87.9^{\mathrm{abc}}$ & 86.1 \\
\hline H 51 & $70.6^{\mathrm{b}}$ & $85.4^{\mathrm{a}}$ & $88.8^{\mathrm{ab}}$ & 81.6 \\
\hline Н 38 & $64.7^{c}$ & $77.4^{\mathrm{b}}$ & $83.4^{\mathrm{bc}}$ & 75.2 \\
\hline H 44 & $61.6^{\mathrm{c}}$ & $75.3^{\mathrm{b}}$ & $82.3^{c}$ & 73.1 \\
\hline Means & 74.0 & 84.4 & 87.8 & 82.4 \\
\hline
\end{tabular}

Means followed by the same letter on columns do not differ significantly by the Student $t$-test at $\mathrm{P}=0.05$.

For both exposure periods ( 48 and $96 \mathrm{~h}$ ), it the hybrids $\mathrm{H} 44$ and $\mathrm{H} 38$ consistently showed the lowest percentage of IGMR, regardless of Al concentration (Table 2). The mean growth inhibition of the main root of these hybrids was 57.6 and $63.8 \%(48 \mathrm{~h})$ and 73.1 and $75.2 \%$ (96 h), respectively. These results confirm that the hybrids H 44 and H 38 are sources of Al tolerance in maize because although aluminum affects normal root development, the magnitude of this effect was lower compared to the values for other hybrids. In contrast, the most 
pronounced action of $\mathrm{Al}$ on IGMR (48 h) was observed for hybrids H 30 (70.7-84.2\%), H 13 (67.8-80.5\%), and $\mathrm{H} 22$ (66.4-78.6\%), confirming the greater sensitivity of these genotypes to Al. At $96 \mathrm{~h}$ exposure (Table 2), the greatest IGMR was for the hybrids $\mathrm{H} 30(80.6-90.6 \%), \mathrm{H}$ 22 (79.1-90.7\%), H 14 (78.5-90.7\%), H 13 (78.4-90.7\%), and H 43 (78.4-87.9\%), confirming the negative effect of this $\mathrm{Al}$ exposure period on the elongation and cell division rate of the main root, as well as the greater sensitivity of these maize hybrids to Al.

During the 2 periods of exposure, strong inhibition of root growth was observed up to $4 \mathrm{mg} / \mathrm{L}$, indicating the potential of the concentrations of 2 and $4 \mathrm{mg} / \mathrm{L}$ of Al in minimal solution for improving the discrimination of maize genotypes to Al tolerance (Figure 5). Prioli et al. (2002) used $4.5 \mathrm{mg} / \mathrm{LAl}$ in complete solution to evaluate the root growth of 2 inbred maize lines (L922, tolerant and Ast214, sensitive) and their progenies ( $\mathrm{F}_{1}, \mathrm{~F}_{2}$, and backcrosses). After 10 days of exposure, marked differences in root growth were observed between tolerant and sensitive strains. Boni et al. (2009) subsequently confirmed the phenotypic differences in Al tolerance between the parental lines at this same concentration.

Discrepancies found in the literature regarding the most appropriate concentration of $\mathrm{Al}$ for identifying sources of Al tolerance in cereal crops may be linked to the genetic basis of the tested genotypes, composition of the nutrient solution, and exposure time and $\mathrm{pH}$ of the solution. Several authors have used concentrations of $4.5 \mathrm{mg} / \mathrm{L} \mathrm{Al}$ (Machado and Pereira, 1990; Paterniani and Furlani, 2002; Prioli et al., 2002; Boni et al., 2009) or 6 mg/L Al (Martins et al., 1999; Sibov et al., 1999; Mazzocato et al., 2002) for this purpose. Other studies, based on complete nutrient solution, adjusted the activity (effective concentration) of Al (27-50 mM) based on the genotypes assessed (Doncheva et al., 2005; Piñeros et al., 2005; Caniato et al., 2007; Maron et al., 2008, 2010).

Most studies that have tested periods of exposure of roots to $\mathrm{Al}$ found decreased root growth after 24-96 h (Piñeros et al., 2005). Doncheva et al. (2005) reported a reduced rate of cell elongation of the main root in a variety of maize that was Al-sensitive after only a 45 -min exposure to $50 \mathrm{mM} \mathrm{Al}$. Maron et al. (2008) found that in the presence of highly contrasting genotypes, only $24 \mathrm{~h}$ exposure to $\mathrm{Al}$ was sufficient for detecting differences in root growth. However, when longer periods of exposure ( $96 \mathrm{~h}$ ) were tested, depending on the Al concentration, the difference between genotypes of contrasting characters is difficult to detect.

Although the reduced root growth increased proportionally with increased Al concentrations, it was not possible to detect significant differences between the hybrids after $96 \mathrm{~h}$ exposure. However, this was presumed to have occurred because the long period of exposure to $\mathrm{Al}$ inhibited the root growth of the studied hybrids with the same intensity at each Al concentration, considering the cumulative effect of Al in the root cells. Maron et al. (2008) studied the accumulation of $\mathrm{Al}$ in the roots of 2 maize genotypes (tolerant and sensitive) exposed to $39 \mathrm{mM} \mathrm{Al}$ and found differences between the genotypes regarding the amount of $\mathrm{Al}$ present in the roots, as well as a growing accumulation of $\mathrm{Al}$ with an increasing exposure period. In the present study, in the experiment with $48 \mathrm{~h}$ of exposure, in addition to the deleterious effect of $\mathrm{Al}$ on root growth, we detected differences between the hybrids at the studied concentrations, which agreed with the results of Mazzocato et al. (2002) and Conceição et al. (2009).

In our study, the period of $48 \mathrm{~h}$ exposure of maize roots to a solution containing 2 $\mathrm{mg} / \mathrm{L} \mathrm{Al}$ enabled us to confirm the suitability of using minimal solution as a fast and efficient approach for selecting genotypes, as well as for identifying sources of Al-tolerance in the hybrids $\mathrm{H} 44$ and $\mathrm{H} 38$. 


\section{REFERENCES}

Alves VMC, Pitta GVE, Parentoni SN, Schaffert RE, et al. (2004). Toxidez por alumínio e hidrogênio no crescimento de raízes de milho. Rev. Bras. Milho Sorgo 3: 311-318.

Boni TA, Prioli AJ, Prioli SMAP, Lucio LC, et al. (2009). Inheritance of aluminum tolerance in maize. Crop Breed. Appl. Biotechnol. 9: 153.

Caires EF, Alleoni LRF, Cambri MA and Barth G (2005). Surface application of lime for crop grain production under a no-till system. Agron. J. 97: 791-798.

Caires EF, Pereira Filho PRS, Zardo Filho R and Feldhaus IC (2008). Soil acidity and aluminium toxicity as affected by surface liming and cover oat residues under a no-till system. Soil Use Manage. 24: 302-309.

Cambraia J, Silva MA, Cano MAO and Sant'anna R (1991). Método simples para a avaliação de cultivares de sorgo quanto à tolerância ao alumínio. Rev. Bras. Fisiol. Veg. 3: 87-95.

Cambraia J and Cambraia MC (1995). Avaliação de híbridos de milho quanto a tolerância ao alumínio, em solução nutritiva. Rev. Ceres 42: 297-307.

Caniato FF, Guimaraes CT, Schaffert RE, Alves VM, et al. (2007). Genetic diversity for aluminum tolerance in sorghum. Theor. Appl. Genet. 114: 863-876.

Clark RB (1975). Characterization of phosphatase of intact maize roots. J. Agric. Food Chem. 23: 458-460.

Coleman NT and Thomas GW (1967). The Basic Chemistry of Soil Acidity. In: Soil Acidity and Liming (Pearson RW and Adams F, eds.). American Society of Agronomy, Madison, 1-41.

Conceição LDHCS, Tessele C and Barbosa Neto JF (2009). Diallel analysis and mapping of aluminum tolerance in corn inbred lines. Maydica 54: 55-61.

Doncheva S, Amenos M, Poschenrieder C and Barcelo J (2005). Root cell patterning: a primary target for aluminium toxicity in maize. J. Exp. Bot. 56: 1213-1220.

Ferreira DF (2011). Sisvar: a computer statistical analysis system. Cienc. Agrotecnol. 35: 1039-1042.

Furlani AMC and Furlani PR (1988). Composição e pH de Soluções Nutritivas para Estudos Fisiológicos e Seleção de Plantas em Condições Nutricionais Adversas. Boletim Técnico n¹21, Instituto Agronômico, Campinas.

Jorge RA and Arruda P (1997). Aluminum-induced organic acid exudation by roots of an aluminum-tolerant tropical maize. Phytochemistry 45: 675-681.

Machado EC and Pereira AR (1990). Eficiência de conversão e coeficiente de manutenção da planta inteira, das raízes e da parte aérea em milho e arroz submetidos ao estresse de alumínio. Pesq. Agropec. Bras. 25: 845-855.

Magnavaca R (1982). Genetic variability and the inheritance of aluminum tolerance in maize (Zea mays L.). Doctoral thesis, University of Nebraska, Lincoln.

Maron LG, Kirst M, Mao C, Milner MJ, et al. (2008). Transcriptional profiling of aluminum toxicity and tolerance responses in maize roots. New Phytol. 179: 116-128.

Maron LG, Pineros MA, Guimaraes CT, Magalhaes JV, et al. (2010). Two functionally distinct members of the MATE (multi-drug and toxic compound extrusion) family of transporters potentially underlie two major aluminum tolerance QTLs in maize. Plant J. 61: 728-740.

Martins PR, Parentoni SN, Lopes MA and Paiva E (1999). Eficiência dos índices fenotípicos de comprimento de raiz seminal na avaliação de plantas individuais de milho quanto à tolerância ao alumínio. Pesq. Agropec. Bras. 34: 1897-1904.

Mazzocato AC, Rocha PSG, Sereno MJCM, Bohnem H, et al. (2002). Tolerância ao alumínio em plântulas de milho. Cienc. Rural 32: 19-24.

Parentoni SN, Alves VMC, Milach SK, Cançado GMA, et al (2001). Recursos Genéticos e Melhoramento - Plantas. In: Melhoramento para Tolerância ao Alumínio como Fator de Adaptação a Solos Acidos (Nass LL, Valois ACC and Melo IS, eds.). Rondonópolis, 783-785.

Paterniani MEAGZ and Furlani PR (2002). Tolerância à toxicidade de alumínio de linhagens e híbridos de milho em solução nutritiva. Bragantia 61: 11-16.

Piñeros MA, Shaff JE, Manslank HS, Alves VM, et al. (2005). Aluminum resistance in maize cannot be solely explained by root organic acid exudation. A comparative physiological study. Plant Physiol. 137: 231-241.

Prioli AJ, Scapim CA, Prioli SMAP, Boni TA, et al. (2002). Genetic analysis of aluminum tolerance in maize. Crop Breed. Appl. Biotechnol. 2: 275-280.

Ribeiro IV Jr and Melo ALP (2008). SAEG: Software Estatístico. Viçosa.

Sibov ST, Gaspar M, Silva MJ, Ottoboni LMM, et al. (1999). Two genes control aluminum tolerance in maize: genetic and molecular mapping analyses. Genome 42: 475-482.

Vitorello VA, Capaldi FRC and Stefanuto VA (2005). Recent advances in aluminum toxicity and resistance in higher plants. Braz. J. Plant Physiol. 17: 129-143. 